\title{
ANALISIS PENERAPAN SISTEM TRANSAKSI NON TUNAI DALAM PENGELOLAAN KEUANGAN DAERAH PADA DINAS LINGKUNGAN HIDUP KOTA BITUNG
}

\author{
Angelina Pelealu ${ }^{1}$, Grace B.Nangoi ${ }^{2}$, Natalia Y.T.Gerungai ${ }^{3}$ \\ 1,2,3 Jurusan Akuntansi, Fakultas Ekonomi dan Bisnis, Universitas Sam Ratulangi, Jl.Kampus Bahu, Manado, \\ 95115, Indonesia \\ E-mail: angel_pelealu19@yahoo.co.id
}

\begin{abstract}
In an effort to improve an efficient regional financial management system, the government issued the Minister of Home Affairs Circular No. 910/1866 / SJ concerning the Implementation of Non-Cash Transactions on April 17, 2017, which is in accordance with the Provisions of Article 283 paragraph (2) of Act Number 23 of 2014 and in accordance with Presidential Instruction Number 10 of 2016 concerning Prevention and Eradication of Corruption. Non-cash transactions are transactions that do not make payments in cash but by way of transfer or transfer between accounts from one party to another. The purpose of this study is to determine the readiness of the process of implementing a non-cash transaction system in the management of regional finances in the Bitung City Environment Agency and to find out what obstacles occur in the process of implementing non-cash transactions in regional financial management in the Bitung City Environmental Service. The research method used is qualitative descriptive. The results of the research, namely the Environmental Office of the city of Bitung has implemented a system of non-cash transactions in stages in the APBD based on Circular of the Minister of Home Affairs No. 910/1866 / SJ. The constraints faced are the administrative process sometimes hampered, the socialization process, its application to the receipt of levies with a small nominal value.
\end{abstract}

Keywords: Analysis, Implementation of Non-Cash Transaction System, Regional Financial Management

\section{PENDAHULUAN}

Dalam upaya peningkatan sistem pengelolaan keuangan daerah yang efisien maka pemerintah menerbitkan Surat Edaran (SE) Menteri Dalam Negeri Nomor 910/ 1866/SJ Tentang Implementasi Transaksi Non Tunai pada 17 April 2017, yang sesuai dengan Ketentuan Pasal 283 ayat (2) Undang-Undang Nomor 23 Tahun 2014 tentang Pemerintahan Daerah, yang mengamanatkan bahwa pengelolaan keuangan daerah dilakukan secara tertib, taat pada peraturan perundang-undangan, efisien, ekonomis, efektif, transparan dan bertanggungjawab dengan memperhatikan rasa keadilan, kepatutan, dan manfaat untuk masyarakat dan sesuai Instruksi Presiden Nomor 10 Tahun 2016 tentang Pencegahan dan Pemberantasan Korupsi. Transaksi non tunai merupakan transaksi yang tidak melakukan pembayaran secara tunai tetapi dengan cara pemindahbukuan atau transfer antar rekening dari satu pihak ke pihak lain.

Di era perkembangan informasi dan teknologi saat ini, penerapan transaksi non tunai dalam pengelolaan keuangan daerah sangat diperlukan untuk mempermudah proses pertanggungjawaban keuangan perangkat daerah dan juga langkah pemerintah untuk mencegah resiko terjadinya penyalahgunaan keuangan di pemerintah daerah. Selain itu, sistem transaksi non tunai dianggap lebih praktis, efisien, mudah, bahkan dapat mendukung perekonomian melalui peningkatan kecepatan peredaran uang. Adapun penerapan sistem non tunai ini merupakan salah satu bentuk untuk mewujudkan pengelolaan keuangan yang transparan dan akuntabel. 
Bitung merupakan salah satu kota yang mulai menerapkan sistem transaksi non tunai pada awal tahun 2018. Dimana penerapannya didasari sesuai dengan Instruksi Presiden Nomor 10 Tahun 2016 tentang Pencegahan dan Pemberantasan Korupsi maupun Surat Edaran Menteri Dalam Negeri No 910/1867/SJ tentang implementasi transaksi non tunai pada pemerintah daerah dan merupakan salah satu langkah strategis dalam mewujudkan good governance yang berbasis teknologi. Untuk memaksimalkan penerapan transaksi non tunai, pemerintah kota Bitung terus melakukan upaya pengembangan dengan mensosialisasikan penerapan non tunai kepada semua pihak yang terkait. Salah satu perangkat daerah di kota Bitung yang mulai menerapkan sistem transaksi non tunai ini adalah Dinas Lingkungan Hidup kota Bitung. Penerapan sistem transaksi non tunai di Dinas Lingkungan Hidup kota Bitung memiliki banyak keuntungan dalam pelaksanaan pengelolaan keuangannya, tetapi juga dalam proses pelaksanaannya memiliki beberapa kendala yaitu dalam proses administrasi, dalam proses sosialisasi, kesulitan untuk menerapannya pada pendapatan retribusi kebersihan yang nominalnya kecil, dan kesiapan sumber daya manusia.

\section{TINJAUAN PUSTAKA}

Akuntansi Pemerintahan Daerah. Halim dkk (2012:40) mendefinisikan bahwa Akuntansi Keuangan Daerah adalah proses pengidentifikasian, pengukuran, pencatatan, dan pelaporan transaksi ekonomi (keuangan) dari entitas pemerintahan daerah (kabupaten, kota, atau provinsi) yang dijadikan informasi dalam rangka pengambilan keputusan ekonomi oleh pihak-pihak eksternal pemerintah daerah yang memerlukan. Akuntansi sektor publik adalah sistem yang dipakai oleh lembaga-lembaga publik sebagai salah satu alat pertanggung jawaban kepada publik (Muindro, 2013:1). Dalam pernyataan Sadeli (2015:4), akuntansi pemerintahan termasuk pula akuntansi lembaga-lembaga non profit atau institutional accounting.

Sistem Akuntansi Pemerintahan Daerah. Nordiawan dan Hertianti (2010:201) menjelaskan bahwa sistem akuntansi pemerintahan daerah adalah serangkaian prosedur mulai dari proses pengumpulan data, pencatatan, pengikhtisaran, sampai dengan pelaporan keuangan dalam rangka pertanggungjawaban pelaksanaan APBD yang dapat dilakukan secara manual atau menggunakan aplikasi komputer. Menurut Rasdianto (2013:6) Sistem akuntansi keuangan daerah adalah sistem akuntansi yang meliputi proses pencatatan, penggolongan, penafsiran, peringkasan transaksi atau kejadian keuangan serta pelaporan keuangan dalam rangka pelaksanaan anggaran pendapatan belanja daerah (APBD). Jadi, sistem akuntansi pemerintahan daerah adalah suatu proses atau prosedur pencatatan keuangan sampai pada pelaporan keuangan dalam melaksanakan dan mempertanggungjawabkan pelaksanaan APBD yang dapat dilakukan secara manual atau menggunakan aplikasi komputer.

Pengelolaan Keuangan Daerah. Permendagri Nomor 21 Tahun 2011 tentang perubahan kedua atas Permendagri Nomor 13 Tahun 2006, pasal 1 ayat (8) menjelaskan Pengelolaan keuangan daerah adalah keseluruhan kegiatan yang meliputi perencanaan, pelaksanaan, penatausahaan, pelaporan, pertanggungjawaban, dan pengawasan keuangan daerah. Pengelolaan keuangan daerah yang diatur dalam peraturan menteri ini meliputi kekuasaan pengelolaan keuangan daerah, azas umum dan struktur APBD, penyusunan rancangan APBD, penetapan APBD, penyusunan dan penetapan APBD bagi daerah yang belum memiliki DPRD, pelaksanaan APBD, perubahan APBD, pengelolaan kas, penatausahaan keuangan daerah, akuntansi keuangan daerah, pertanggungjawaban pelaksanaan APBD, pembinaan dan pengawasan pengelolaan keuangan daerah, kerugian daerah, dan pengelolaan keuangan BLUD. Chabib dan Heru (2010:10) menjelaskan ada 5 prinsip dalam pengelolaan keuangan yang diperlukan untuk mengontrol kebijakan keuangan 
daerah meliputi: (1) akuntabilitas; (2) Value for Money; (3) kejujuran dalam mengelola keuangan publik (Probity); (4) transparansi; dan (5) pengendalian.

\section{Sistem dan Prosedur Penatausahaan Keuangan Daerah}

Penatausahaan Penerimaan Daerah. Dalam Permendagri Nomor 21 Tahun 2011 tentang perubahan kedua atas Permendagri 13 Tahun 2006 tentang Pedoman Pengelolaan Keuangan Daerah, menjelaskan sistem dan prosedur penatausahaan penerimaan atau pendapatan daerah sebagai berikut:

1. Sistem dan prosedur pendapatan daerah melalui bendahara penerimaan

2. Sistem dan prosedur pendapatan daerah melalui bendahara penerimaan pembantu

3. Sistem dan prosedur pendapatan daerah melalui bank pemerintah yang ditunjuk, bank lain, badan, lembaga keuangan, dan/atau kantor pos

4. Pertanggungjawaban bendahara penerimaan

5. Pertanggungjawaban bendahara penerimaan pembantu

Penatausahaan Pengeluaran Daerah. Dalam Permendagri Nomor 21 Tahun 2011 tentang perubahan kedua atas Permendagri 13 Tahun 2006 tentang pedoman pengelolaan keuangan daerah, sistem dan prosedur penatausahaan pengeluaran atau belanja daerah dijelaskan sebagai berikut: Anggaran Kas, Pembuatan Surat Penyediaan Dana, Pengajuan Surat Permintaan Pembayaran (SPP), Penerbitan Surat Perintah Membayar (SPM), Penerbitan Surat Perintah Pencairan Dana (SP2D), Pelaksanaan Belanja untuk Penggunaan Uang Persediaan (UP), Pembuatan Surat Pertanggungjawaban (SPJ) Pengeluaran.

Penerapan Sistem Transaksi Non Tunai. Penerapan Sistem Transaksi Non Tunai didasari oleh instruksi Presiden Nomor 10 Tahun 2016 tentang Pencegahan dan Pemberantasan Korupsi maupun Surat Edaran Menteri Dalam Negeri No 910/1867/SJ tentang implementasi transaksi non tunai pada pemerintah daerah. Penerapan Transaksi Non Tunai merupakan upaya pemerintah dalam meningkatkan pengelolaan keuangan daerah, ini sesuai dengan Ketentuan Pasal 283 ayat (2) Undang-Undang Nomor 23 Tahun 2014 tentang Pemerintahan Daerah, yang mengamanatkan bahwa pengelolaan keuangan daerah dilakukan secara tertib, taat pada peraturan perundang-undangan, efisien, ekonomis, efektif, transparan dan bertanggungjawab dengan memperhatikan rasa keadilan, kepatutan, dan manfaat untuk masyarakat. Dalam upaya peningkatan akuntabilitas dan transparansi pengelolaan keuangan, maka pemerintah melakukan upaya percepatan implementasi transaksi non tunai di pemerintahan daerah yang dijelaskan dalam Surat Edaran Menteri Dalam Negeri No 910/1867/SJ tentang implementasi transaksi non tunai pada pemerintah daerah, sebagai berikut:

1. Transaksi non tunai merupakan pemindahan sejumlah nilai uang dari satu pihak ke pihak lain dengan menggunakan instrument berupa Alat pembayaran Menggunakan Kartu (APMK), cek, bilyet giro, uang elektronik atau sejenisnya.

2. Pelaksanaan transaksi non tunai pada pemerintah daerah dilaksanakan paling lambat tanggal 1 Januari 2018 yang meliputi seluruh transaksi: (a) penerimaan daerah yang dilakukan oleh bendahara penerimaan/bendahara penerimaan pembantu; dan (b) pengeluaran daerah yang dilakukan oleh bendahara pengeluaran/ bendahara pengeluaran pembantu.

3. Melakukan koordirnasi dengan lembaga keuangan bank dan/atau lembaga keuangan bukan bank terkait di daerah.

4. Gubernur menetapkan kebijakan implementasi transaksi non tunai serta menyusun rencana aksi atas pelaksanaan kebijakan dimaksud.

5. Pemerintah daerah dapat melaksanakan transaksi non tunai secara bertahap dengan melakukan pembatasan penggunaan uang tunai dalam pelaksanaan transaksi penerimaan oleh bendahara penerimaan/bendahara penerimaan pembantu dan transaksi pengeluaran 
oleh bendahara pengeluaran/bendahara pengeluaran pembantu yang ditetapkan oleh Gubernur.

6. Gubernur melaporkan perkembangan kesiapan implementasi transaksi non tunai pada pemerintah provinsi dan melakukan monitoring/evaluasi atas implementasi transaksi non tunai pada kabupaten/kota di wilayahnya masing-masing untuk selanjutnya melaporkan perkembangan kesiapan implementasi transaksi non tunai dimaksud kepada Menteri Dalam Negeri.

\section{METODE PENELITIAN}

Jenis Penelitian. Penelitian ini merupakan jenis penelitian deskritif kualitatif. Penelitian deskritif kualitatif ini bertujuan untuk memperoleh informasi keadaan yang terjadi saat penelitian berlangsung dengan menyuguhkan apa yang sebenarnya terjadi. Menurut Meleong (2014:6), penelitian kualitatif adalah penelitian yang bermaksud untuk memahami tentang apa yang dialami oleh subjek penelitian, misalnya: perilaku, persepsi, dan motivasi.

Tempat dan Waktu Penelitian. Lokasi penelitian di Dinas Lingkungan Hidup Kota Bitung. Penelitian dilaksanakan pada bulan Maret 2018-April 2018.

Jenis dan Sumber Data. Dalam penelitian ini peneliti memakai jenis data kualitatif. Sumber data yang digunakan yaitu sumber data primer yang diperoleh langsung dari objek penelitian di Dinas Lingkungan Hidup Kota Bitung melalui wawancara, observasi langsung, dan kajian dokumen yang diambil.

Metode Pengumpulan Data. Data dalam penulisan penelitian ini dikumpulkan dengan menggunakan metode:

1. Wawancara. Wawancara merupakan teknik pengumpulan data dengan cara mengajukan pertanyaan-pertanyaan kepada pihak-pihak yang terkait dengan penelitian.

2. Observasi. Metode ini digunakan untuk mempelajari secara langsung kesiapan dan proses penerapan sistem transaksi non tunai dalam pelaksanaan anggaran pada objek penelitian serta untuk mengetahui keakuratan data dengan membandingkan hasil wawancara dengan keadaan sebenarnya.

3. Kajian dokumen. Metode ini digunakan untuk memperoleh data mengenai teori-teori atau dokumen-dokumen yang terkait dengan proses penerapan transaksi non tunai dalam pengelolaan keuangan di Dinas Lingkungan Hidup Kota Bitung.

Metode Analisis Data. Analisis data adalah proses mencari dan menyusun secara sistematis data yang diperoleh dari wawancara, catatan lapangan, dan dokumentasi, dengan cara mengorganisasikan data ke dalam kategori, menjabarkan ke dalam unit-unit, melakukan sintesa, menyusun ke dalam pola, memilih mana yang penting dan yang akan dipelajari, dan membuat kesimpulan sehingga mudah dipahami oleh diri sendiri maupun orang lain (Sugiyono, 2016:147). Metode penelitian yang digunakan dalam penelitian ini adalah metode deskriptif. Menurut Sugiyono (2012:29) metode deskriptif adalah metode yang digunakan untuk menggambar atau menganalisis suatu hasil penelitian tetapi tidak digunakan untuk membuat kesimpulan yang lebih luas.

\section{HASIL PENELITIAN DAN PEMBAHASAN}

\subsection{Hasil Penelitian}

Kesiapan Dinas Lingkungan Hidup kota Bitung dalam Penerapan Sistem Transaksi Non Tunai. Dalam wawancara yang dilakukan dengan Informan 1 yaitu Sekretaris Dinas Lingkungan Hidup Kota Bitung. Informan 1 menjelaskan bahwa Dinas Lingkungan Hidup sudah cukup siap dalam penerapan sistem transaksi non tunai ini. Penerapan sistem transaksi non tunai ini sudah mulai diterapkan pada awal Januari 2018 dan dilakukan secara bertahap pada Pendapatan dan Belanja. Hasil wawancara dengan 
informan 3 yaitu bendahara penerimaan, bahwa Dinas Lingkungan Hidup telah cukup siap untuk penerapan sistem transaksi non tunai ini. Akan tetapi dalam penerimaan pendapatan daerah di Dinas Lingkungan Hidup belum diterapkan sepenuhnya pada setiap pendapatan retribusi karena masih ada kesulitan-kesulitan dalam penerapannya. Berdasarkan hasil wawancara dengan beberapa informan di Dinas Lingkungan Hidup maka ditemukan hasil mengenai kesiapan Dinas Lingkungan Hidup kota Bitung dalam penerapan sistem transaksi non tunai ini, yaitu dalam penerapan sistem transaksi non tunai akan dilakukan secara bertahap dan akan terus disosialisasikan kepada masyarakat dan pihak-pihak terkait, masih ada beberapa post anggaran pendapatan dan pengeluaran daerah yang belum menerapkan sistem transaksi non tunai ini karena memiliki beberapa kesulitan dalam penerapannya.

Landasan Hukum Penerapan Sistem Transaksi Non Tunai di Dinas Lingkungan Hidup. Dasar diterapkannya sistem transaksi non tunai dalam pengelolaan keuangan di Dinas Lingkungan Hidup Kota Bitung yaitu sesuai dengan arahan Walikota Bitung dalam Sosialisasi yang dilakukan di akhir tahun 2017 dan sesuai dengan Instruksi Presiden Nomor 10 Tahun 2016 tentang Pencegahan dan Pemberantasan Korupsi serta Surat Edaran Menteri Dalam Negeri No 910/1867/SJ tentang implementasi transaksi non tunai pada pemerintah daerah. Undang-Undang Nomor 23 Tahun 2014 Pasal 283 ayat (2) juga merupakan dasar pemerintah dalam penerapan sistem transaksi non tunai. Ketentuan Pasal 283 ayat (2) Undang-Undang Nomor 23 Tahun 2014 tentang Pemerintahan Daerah, yang mengamanatkan bahwa pengelolaan keuangan daerah dilakukan secara tertib, taat pada peraturan perundangundangan, efisien, ekonomis, efektif, transparan dan bertanggungjawab dengan memperhatikan rasa keadilan, kepatutan, dan manfaat untuk masyarakat.

\section{Proses Penerapan Sistem Transaksi Non Tunai di Dinas Lingkungan Hidup Kota Bitung}

Penerapan Sistem Transaksi Non Tunai pada Penerimaan. Hasil wawancara dengan Informan 3 yaitu Bendahara Penerimaan menjelaskan bahwa dalam pendapatan daerah proses sistem transaksi non tunai dilakukan dengan cara wajib pajak atau wajib retribusi menyetorkan pajak atau retribusi melalui bank atau rekening kepada bendahara penerimaan atau langsung kepada BUD. Sumber pendapatan yang ada di Dinas Lingkungan Hidup kota Bitung yaitu Retribusi Kebersihan. Restribusi kebersihan merupakan pemungutan pembayaran atas kebersihan yang dipungut kepada wajib retribusi kota Bitung yang telah diatur dalam peraturan pemerintah kota Bitung. Wajib retribusi kota Bitung meliputi perusahaan besar, usaha kecil menengah, pedagang pasar, dan rumah tangga. Dalam pelaksanaannya sistem transaksi non tunai belum sepenuhnya diterapkan pada Pendapatan di Dinas Lingkungan Hidup, ini karena penerimaan retribusi kebersihan itu bervariasi mulai dari Rp.5000 hingga Ratusan ribu. Untuk retribusi kebersihan pada perusahaan besar penyetorannya sudah langsung ke rekening pemerintah dan untuk retribusi kebersihan dengan nominal kecil seperti di retribusi kebersihan rumah tangga, industri kecil, dan pasar, masih di tagih langsung oleh petugas-petugas yang telah diberi tanggungjawab untuk menagih retribusi kebersihan. Proses penerimaan retribusi yaitu pengguna anggaran akan menyerahkan surat ketetapan retribusi kepada bendahara penerimaan, kemudian bendahara penerimaan akan menyerahkan surat ketetapan retribusi tersebut kepada wajib retribusi, selanjutnya bendarahara akan menagih retribusi kepada wajib retribusi. Retribusi kebersihan dengan nominal besar akan membayarkan retribusi langsung di bank SULUT kepada rekening pemerintah daerah atau BUD, kemudian bank SULUT akan mengeluarkan slip pembayaran dan nota kredit. Slip pembayaran nantinya akan di berikan kepada wajib retribusi kemudian diberikan kepada bendahara penerimaan sebagai bukti yang sah untuk dibuat dokumen pertanggungjawaban. Untuk nota kredit akan diberikan kepada Bendahara Umum Daerah. Retribusi dengan nominal kecil pembayarannya masih dilakukan dengan 
cara kolektor atau petugas penagih akan menagih uang retribusi tersebut secara langsung kepada wajib retribusi kemudian disetorkan kepada bendahara penerimaan dengan buktibukti yang sah kemudian bendahara penerimaan akan membuat dokumen pertanggungjawaban yang kemudian menyetor penerimaan retribusi tersebut kepada rekening BUD.

Penerapan Sistem Transaksi Non Tunai pada Pengeluaran. Pengelolaan anggaran belanja di Dinas Lingkungan Hidup menggunakan 3 jenis pembayaran yaitu UP, GU, dan LS. Untuk mekanisme pembayaran UP/GU yaitu bendahara pengeluaran akan membuat SPP UP/GU, kemudian SPP UP/GU tersebut diserahkan kepada PPK-SKPD untuk membuat SPM UP/GU yang kemudian akan disetujui dan ditandatangani oleh pengguna anggaran, selanjutnya bendahara akan membawa berkas-berkas tagihan tersebut ke BUD beserta dokumen pendukung lainnya untuk memproses dokumen SP2D. Melalui SP2D tersebut maka bendahara dapat melakukan pencairan dana dan pembayaran yang pada saat ini sudah diberlakukan secara non tunai. Selanjutnya dalam pembayaran LS mekanismenya hampir sama dengan pembayaran UP/GU hanya saja dalam pembayaran LS PPTK yang akan menyiapkan dokumen dari pihak ke-3 dan menandatangani SPP-LS (Kalau dalam pembayaran UP/GU PPTK tidak perlu menandatangani SPP UP/GU, disini PPTK hanya memverifikasi kelengkapan berkas) yang kemudian bendahara akan menyerahkan berkas SPP-LS kepada PPK-SKPD untuk dibuatkan SPM-LS dan kemudian ditandatangi oleh Pengguna anggaran setelah itu bendahara akan membawa SPM-LS tersebut kepada BUD untuk memproses SP2D, setelah SP2D diterbitkan dana langsung di transfer dari rekening BUD kepada pihak ke 3.

\section{Keuntungan dan Kendala yang dihadapi dalam Proses Penerapan Sistem Transaksi Non Tunai}

Keuntungan. Dari hasil wawancara, ada beberapa keuntungan yang dihadapi dalam penerapan sistem transaksi non tunai:

1. Penggunaan aliran dana seluruh transaksi dapat ditelusuri sehingga lebih akuntabel, dikarenakan seluruh transaksi didukung dengan bukti yang sah.

2. Bendahara tidak harus memegang uang tunai dengan berbagai resiko kejahatan, kehilangan, dan kesalahan hitung.

3. Menghindari penyalahgunaan keuangan di perangkat daerah.

4. Penggunaan anggaran lebih efisien dan arus keluar masuk kas lebih terkontrol.

5. Meningkatkan pengendalian internal pengelolaan kas.

6. Mempermudah bendahara penerimaan dalam penagihan retribusi kebersihan, karna sebagian penagihannya sudah langsung dibayarkan oleh wajib retribusi lewat bank atau rekening.

Kendala. Dalam wawancara yang dilaksanakan di Dinas Lingkungan Hidup kota Bitung, peneliti mengajukan pertanyaaan kepada informan mengenai apa saja kendala yang dihadapi dalam penerapan sistem non tunai. Dari hasil wawancara, ada beberapa kendala yang dihadapi dalam penerapan sistem transaksi non tunai:

1. Sulit menerapkan sistem transaksi non tunai pada penerimaan retribusi kebersihan yang nominal pembayarannya kecil.

2. Masalah internal dalam pembuatan SPTD yang mengalami keterlambatan, disebabkan karena dokumen pendukung pembuatan SPTD yang belum lengkap pada saat proses pembuatan SPTD. Contoh yang menyebabkan belum lengkapnya dokumen pendukung pembuatan SPTD yaitu daftar pembayaran yang terlambat ditandatangani oleh pihak ketiga (tenaga kerja kebersihan) dan pengguna anggaran yang tidak ada di tempat pada saat penandatanganan dokumen SPTD. Keterlambatan pembuatan SPTD akan menyebabkan proses pencairan dana atau transfer dana terlambat. Dokumen-dokumen 
pendukung yang digunakan untuk pembuatan SPTD seperti daftar pembayaran, rekapitulasi data tenaga kerja kebersihan, daftar belanja barang.

3. Masalah external yaitu dari pihak administrasi bank yang terlambat memproses pencairan dana dikarenakan gangguan server di bank atau kurangnya pelayanan.

\subsection{Pembahasan}

Analisis Penerapan Sistem Transaksi Non Tunai di Dinas Lingkungan Hidup

Kota Bitung. Berdasarkan Surat Edaran Menteri Dalam Negeri No 910/1867/SJ tentang implemetasi transaksi non tunai pada pemerintah daerah yang diterbitkan pada 17 April 2017, maka pemerintah kota Bitung mulai menerapkan sistem transaksi non tunai pada awal tahun 2018. Penerapan sistem transaksi non tunai ini merupakan salah satu bentuk komitmen pemerintah kota Bitung dalam menjalankan peraturan perundang-undangan yang berlaku. Berdasarkan instruksi walikota bitung, per tanggal 1 Januari 2018 Dinas Lingkungan Hidup kota Bitung sudah mulai menerapkan sistem transaksi non tunai dalam pelaksanaan anggaran di dinas tersebut. Berdasarkan hasil wawancara dengan beberapa informan di Dinas Lingkungan Hidup maka ditemukan hasil mengenai kesiapan Dinas Lingkungan Hidup kota Bitung dalam penerapan sistem transaksi non tunai ini, yaitu penerapan dilakukan secara bertahap dan akan terus disosialisasikan kepada masyarakat dan pihak-pihak terkait. Dalam penerimaan retribusi daerah sistem transaksi non tunai belum diterapkan secara keseluruhan karena memiliki beberapa kesulitan dalam penerapannya.

Sistem Transaksi Non Tunai pada Penerimaan. Pada pendapatan daerah, proses sistem transaksi non tunai dilakukan dengan cara wajib pajak atau wajib retribusi menyetorkan pajak atau retribusi melalui bank atau rekening kepada bendahara penerimaan atau langsung kepada BUD. Sumber pendapatan yang ada di Dinas Lingkungan Hidup kota Bitung yaitu Retribusi Kebersihan. Penerapan sistem transaksi non tunai belum sepenuhnya diterapkan pada Pendapatan di Dinas Lingkungan Hidup Kota bitung, alasannya karena pendapatan retribusi dengan jumlah kurang dari Rp.20.000,- masih sulit diterapkan secara non tunai. Penerimaan retribusi daerah disetor ke rekening kas umum daerah atau BUD oleh bendahara penerimaan pada bank pemerintah yang ditunjuk (bank SULUT) dan dianggap sah setelah kuasa BUD menerima nota kredit, dilakukan dengan cara: (a) disetor langsung ke bank oleh pihak ketiga; dan (b) disetor melalui bendahara penerimaan oleh pihak ketiga.

Sistem Transaksi Non Tunai pada Pengeluaran. Sistem transaksi non tunai pada pengeluaran yaitu pembayaran yang dilakukan dengan mentranfer atau memindahbukukan dana dari rekening bendahara ke rekening pihak ke 3 yang akan menerima dana tersebut. Langkah-langkah teknis dalam pelaksanaan belanja di Dinas Lingkungan Hidup kota Bitung:

1. Pengajuan SPP UP/GU/LS oleh Bendahara Pengeluaran.

2. Bendahara menyerahkan SPP UP/GU/LS beserta dokumen lainnya kepada PPK-SKPD untuk diteliti kelengkapan dokumen dan kesesuaiannya.

3. SPP UP/GU yang dinyatakan lengkap dibuatkannya rancangan SPM oleh PPK-SKPD. Rancangan SPM ini kemudian diberikan kepada Pengguna Anggaran untuk di otorisasi.

4. Pengguna Anggaran menyerahkan SPM kepada kuasa BUD untuk diteliti kelengkapan berkas SPM yang diajukan. Apabila SPM dinyatakan lengkap Kuasa BUD akan menerbitkan SP2D.

5. BUD akan menyerahkan SP2D kepada Bank dan Pengguna Anggaran.

6. Pengguna Anggaran menyerahkan SP2D kepada Bendahara Pengeluaran.

7. Berdasarkan SP2D yang diterima, bank mencairkan dana atau mentransfer dana ke rekening bendahara. 
8. Untuk menggunakan dana dari rekening, bendahara akan membuat SPTD (Surat Perintah Transfer Dana) yang akan disetujui oleh Pengguna Anggaran, kemudian SPTD akan di berikan ke bank.

9. Berdasarkan SPTD yang diterima, bank mentransfer dana sesuai SPTD kepada pihak ketiga.

10. Bank kemudian akan membuat nota debet dan menyerahkannya kepada bendahara pengeluaran.

Solusi Terhadap Kendala Yang Dihadapi Dalam Proses Penerapan Sistem Transaksi

Non Tunai. Dalam penerapan sistem transaksi non tunai ada beberapa kendala yang di hadapi setiap instansi dalam pelaksanaannya. Berikut kendala-kendala dalam Penerapan Sistem Transaksi Non Tunai pada Pengelolaan Keuangan Daerah di Dinas Lingkungan Hidup kota Bitung:

1. Sulit menerapkan sistem transaksi non tunai pada penerimaan retribusi kebersihan yang nominal pembayarannya kecil.

2. Kendala penerapan sistem transaksi non tunai pada pengeluaran yaitu pembuatan SPTD yang mengalami keterlambatan, disebabkan karena dokumen pendukung pembuatan SPTD yang belum lengkap pada saat proses pembuatan SPTD. Contoh yang menyebabkan belum lengkapnya dokumen pendukung pembuatan SPTD yaitu daftar pembayaran yang terlambat ditandatangani oleh pihak ketiga (tenaga kerja kebersihan) dan pengguna anggaran yang tidak ada di tempat pada saat penandatanganan dokumen SPTD. Keterlambatan pembuatan SPTD akan menyebabkan proses pencairan dana atau transfer dana terlambat. Dokumen-dokumen pendukung yang digunakan untuk pembuatan SPTD seperti daftar pembayaran, rekapitulasi data tenaga kerja kebersihan, daftar belanja barang.

3. Masalah external yaitu dari pihak administrasi bank yang terlambat memproses pencairan dana dikarenakan gangguan server di bank atau kurangnya pelayanan.

Adapun solusi dalam menghadapi kendala pada proses penerapan sistem transaki non tunai, yaitu sebagai berikut:

1. Dalam penagihan retribusi daerah, pemerintah bisa bekerja sama dengan pihak bank yang telah ditunjuk (dalam hal ini bank SULUT) dengan membuat kartu e-money dan fasilitas konter-konter khusus pembayaran retribusi kebersihan di beberapa tempat seperti di daerah pasar. Para wajib retribusi dapat membayar retribusi kebersihan lewat konter-konter tersebut, bisa secara tunai dan juga bisa menggunakan e-money. Untuk menanggulangi para wajib retribusi tidak membayar retribusi maka pemerintah dapat melakukan pengawasan atau pengecekan apakah wajib retribusi telah membayar retribusi atau tidak. Pemerintah juga harus mempertegas peraturan atau sanksi terhadap wajib retribusi yang tidak melakukan pembayaran retribusi kebersihan. Perlu juga melakukan sosialisasi kepada wajib retribusi mengenai penerapan sistem transaksi non tunai.

2. Dalam proses administrasi pencairan dana atau transfer dana agar tidak mengalami keterlambatan maka proses pengumpulan dokumen dan pembuatan SPTD harus dipercepat. SPTD sebaiknya dibuat paling lambat sehari sebelum pencairan dana atau sebelum tanggal jatuh tempo pencairan dana, agar pada saat jatuh tempo tidak mengalami keterlambatan mentransfer dana atau mencairkan dana. Keterlambatan pencairan dana seperti ini dapat mempengaruhi kinerja keuangan maupun kinerja pemerintahan di Dinas Lingkungan Hidup kota Bitung. Untuk masalah pembayaran upah buruh, sebaiknya penandatanganan daftar pembayaran bisa di lakukan sehari sebelum mentransfer dana atau pada jumat pagi sebelum mentransfer dana. Untuk 
pengguna anggaran sebaiknya berada ditempat pada saat pencairan dana dan bendahara perlu berkoordinasi dengan pengguna anggaran kapan saja tanggal-tanggal pencairan dana. Jika pada saat pencairan dana pengguna anggaran memiliki tugas luar maka bendahara dapat menanggulanginya dengan membuat dokumen pencairan dana sehari lebih cepat sebelum pengguna anggaran melaksanakan tugas luar.

3. Melakukan pengendalian internal pada pengelolaan keuangan dengan melakukan pengawasan dan pengecekan kelengkapan dokumen dalam proses administrasi pencairan dana sehari sebelum tanggal pencairan dana atau mentransfer dana. Dengan melakukan pengendalian internal dapat meningkatkan kinerja keuangan dalam pengelolaan keuangan di Dinas Lingkungan Hidup.

4. Pemerintah dapat mengajukan kepada pihak bank yang telah ditunjuk sebagai bank kas daerah untuk menambah SDA di bank tersebut, dan juga pihak bank perlu meningkatkan kinerja pelayanan.

\section{KESIMPULAN DAN SARAN}

\subsection{Kesimpulan}

Berdasarkan dari hasil penelitian dan pembahasan, maka diambil kesimpulan sebagai berikut:

1. Penerapan sistem transaksi non tunai di Dinas LIngkungan Hidup kota Bitung di terapkan secara bertahap berdasarkan Surat Edaran Menteri Dalam Negeri No 910/1867/SJ tentang implemetasi transaksi non tunai pada pemerintah daerah.

2. Keuntungan penerapan sistem transaksi non tunai di Dinas Lingkungan Hidup kota Bitung yaitu, penggunaan aliran dana seluruh transaksi dapat ditelusuri sehingga lebih akuntabel, dikarenakan seluruh transaksi didukung dengan bukti yang sah; bendahara tidak harus memegang uang tunai dengan berbagai resiko kejahatan, kehilangan, dan kesalahan hitung; menghindari penyalahgunaan keuangan di perangkat daerah; penggunaan anggaran lebih efisien dan arus keluar masuk kas lebih terkontrol; meningkatkan pengendalian internal pengelolaan kas; dan mempermudah bendahara penerimaan dalam penagihan retribusi kebersihan, karna sebagian penagihannya sudah langsung dibayarkan oleh wajib retribusi lewat bank atau rekening.

3. Dalam penerapan sistem transaksi non tunai ada beberapa kendala-kendala yang dihadapi oleh Dinas Lingkungan Hidup kota Bitung adalah sebagai berikut: Sulit menerapkan sistem transaksi non tunai pada penerimaan retribusi kebersihan yang nominal pembayarannya kecil; Masalah internal dalam pembuatan SPTD yang mengalami keterlambatan, disebabkan karena dokumen pendukung pembuatan SPTD yang belum lengkap pada saat proses pembuatan SPTD. Contoh yang menyebabkan belum lengkapnya dokumen pendukung pembuatan SPTD yaitu daftar pembayaran yang terlambat ditandatangani oleh pihak ketiga (tenaga kerja kebersihan) dan pengguna anggaran yang tidak ada di tempat pada saat penandatanganan dokumen SPTD. Keterlambatan pembuatan SPTD akan menyebabkan proses pencairan dana atau transfer dana terlambat. Dokumen-dokumen pendukung yang digunakan untuk pembuatan SPTD seperti daftar pembayaran, rekapitulasi data tenaga kerja kebersihan, daftar belanja barang; Masalah external yaitu dari pihak administrasi bank yang terlambat memproses pencairan dana dikarenakan gangguan server di bank atau kurangnya pelayanan.

\subsection{Saran}

Saran dan solusi yang bisa penulis berikan berdasarkan dari hasil analisis dan kesimpulan, yaitu: 
1. Untuk menghadapi kendala dalam penerapan system transaksi non tunai ini, maka pemeritah perlu membuat kebijakan-kebijakan lain seperti strategi, pengendalian penggunaan anggaran, kebijakan penggunaan sistem, dan lain-lain. Perlu juga dibuat aturan atau prosedur mengenai penerapan sistem transaksi non tunai ini, agar tujuan penerapan sistem transaksi non tunai ini bisa terlaksana dengan maksimal.

2. Dalam penagihan retribusi daerah, pemerintah bisa bekerja sama dengan pihak bank yang telah ditunjuk (dalam hal ini bank SULUT) dengan membuat kartu e-money dan fasilitas konter-konter khusus pembayaran retribusi kebersihan di beberapa tempat seperti di daerah pasar. Para wajib retribusi dapat membayar retribusi kebersihan lewat konter-konter tersebut, bisa secara tunai dan juga bisa menggunakan e-money. Perlu juga melakukan sosialisasi kepada wajib retribusi mengenai penerapan sistem transaksi non tunai.

3. Dinas Lingkungan Hidup Kota Bitung dapat melakukan pengendalian internal pada pengelolaan keuangan dengan meningkatkan pengawasan dan pengecekan kelengkapan berkas dalam proses administrasi pencairan dana sehari sebelum tanggal pencairan dana atau mentransfer dana. Dengan melakukan pengendalian internal dapat meningkatkan kinerja keuangan dalam pengelolaan keuangan di Dinas Lingkungan Hidup.

4. Pemerintah lebih meningkatkan kerja sama dengan pihak bank. Pemerintah dapat menganjurkan kepada pihak bank yang telah ditunjuk (Bank SULUT) sebagai bank kas daerah untuk menambah SDA di bank tersebut, dan juga pihak bank perlu meningkatkan kinerja pelayanan.

\section{DAFTAR PUSTAKA}

Abdul Halim dan Muhammad Syam Kusufi, 2012. Akuntansi Sektor Publik Akuntansi Keuangan Daerah. Edisi 4. Jakarta: Salemba Empat.

Chabib Sholeh dan Heru Rochmansjah, 2010. Pengelolaan Keuangan dan Aset Daerah Sebuah Pendekatan Struktural Menuju Tata Kelola Pemerintahan Yang Baik. Bandung: Fokusmedia.

Deddi Nordiawan dan Ayuningtyas Hertianti, 2010. Akuntansi Sektor Publik. Edisi 2. Penerbit: Salemba Empat.

Erlina Rasdianto. 2013. Akuntansi Keuangan Daerah Berbasis Akrual. Medan: Brama Ardian.

Moleong, Lexy J. 2014. Metodologi Penelitian Kualitatif. Bandung: PT Remaja Rosdakarya. Muindro Renyowijoyo. 2013. Akuntansi Sektor Publik. Jakarta : Mitra Wacana Media Peraturan Menteri Dalam Negeri Nomor 21 Tahun 2011 Pedoman Pengelolaan Keuangan Daerah. Menteri Dalam Negeri Republik Indonesia. Jakarta.

Sadeli, Lili. 2015. Dasar-Dasar Akuntansi. Edisi Pertama. Jakarta: Bumi Aksara.

Sugiyono. 2012.Metode Penelitian Bisnis. Bandung : Alfabeta. 2015.Metode Penelitian Bisnis. Bandung : Alfabeta

2016. Metodologi Penelitian Kuantitatif, Kualitatif, dan R\&D. Bandung: CV Alfabeta.

Surat Edaran Menteri Dalam Negeri Nomor 910/ 1866/SJ Tentang Implementasi Transaksi Non Tunai. 17 April 2017. Jakarta.

Undang-Undang Nomor 23 Tahun 2014 Pemerintahan Daerah. 30 September 2014. Lembaran Negara Republik Indonesia. Jakarta. 